\title{
The Relationship between Natural Environment Relatedness and Emotional Well-Being: A Systematic Review and Proposed Conceptual Framework
}

\author{
Noorlila Ahmad \\ Kulliyyah of Education, \\ International Islamic University Malaysia, \\ Kuala Lumpur, Malaysia \\ noorlila@iium.edu.my
}

\author{
Siti Fatimah Abd Rahman \\ Kulliyyah of Education, \\ International Islamic University Malaysia, \\ Kuala Lumpur, Malaysia \\ sfarahman@iium.edu.my
}

\begin{abstract}
The influence of the natural environment on emotional well-being has been highlighted at the peak of the Covid 19 pandemic that saw most countries impose prolonged total lockdowns and movement restrictions on their citizens. While researchers have recently emphasized the need to focus not only on students' academic achievement but also on their inner needs, which include their emotional well-being, studies have found nature connectedness has a positive effect on emotional well-being and physical health. Many studies on nature and well-being have focused on physiological and psychological experimental research to examine before and after exposure to nature. However, there is still a need for further investigation how emotional connection between nature environments in the aspect of restorativeness and spiritual values improve mental health. This paper systematically reviewed previous studies about the relationship between exposure to the natural environment and well-being focusing on key variables, underpinning theories, methodological processes and samples. As a result of the review, a conceptual framework is proposed for future studies on relationship between exposure to the natural environment and well-being. We hope that the proposed framework will be empirically tested in future studies.
\end{abstract}

Keywords: Natural environment, ecopsychology, restorativeness, spiritual values, stress, anxiety, depression, emotional well-being 


\section{INTRODUCTION}

Researchers and practitioners have grappled with the substantial rise in emotional disturbances among graduate students for more than a decade (Ahmad et al., 2018; Zafirah et al., 2016). WHO (2008) estimated that mental health issues would increase by 15 per cent by 2020 and increased more due to pandemic COVID-19 presently. The increasing trend of mental illness cases is so significant that it requires urgent attention, particularly among university students who have been found to experience very high levels of stress (Down \& Eisenbery, 2012).

Previous studies on emotional disturbances among undergraduate students have attributed their stress, anxiety, and depression to psychological distress. Causes included demographic, psychosocial, academic, financial, relationship, communication factors, in addition to consumption of alcohol and drugs, diet, leading a sedentary lifestyle and internet usage (Said et al., 2013; Wahed \& Hassan, 2017; Xu et al., 2016). Emotional disorders seriously affect undergraduates' psychological and physiological well-being (Franken, 1994). Among the effects were mental fatigue (Nisbet et al., 2011), cognitive constraints (Park et al., 2011), lack of focus and attention (Kaplan \& Kaplan, 1989) and poor anger management or aggression (Kuo \& Sullivan, 2001; Park et al., 2011). For undergraduates, poor emotional well-being resulted into academic underachievement, low self-esteem, dropping out from college and even suicide attempt (Law, 2007). Many of the reviewed studies have reported on appropriate resolutions, especially those related to providing psychological support to help relieve the undergraduates' emotional disturbances.

Findings from previous studies suggested that a conducive environment area is an important psychological resource that helps individuals to act more positively (Hartig et al., 2001). Nature or green space has been considered as a psychological support for self-resting and reducing stress (Hartig \& Staats, 2006; Kaplan \& Kaplan, 1989). Whereas previous empirical evidence proved that exposure to the natural environment or green space improves health (Annerstedt \& Währborg, 2011), Nabilla et al., (2018) found nature-based experiences to be a less popular form of recreation activity, particularly among the younger generation. Therefore, there is a room to examine further the emotional connection among younger generation towards nature-based experiences to lessen their levels of stress and increase mental benefits.

A nature-based environment induces an emotional sense of pleasure, calmness, and relaxation (Bell, 2012). Evidence from earlier findings has shown that practicing spiritual values significantly reduces emotional upheavals and improves well-being (Reave, 2005; Yadav, 2017). In addition to creating emotional stability, enhancing balance, and improving health, spirituality also protects from modern materialistic demands and brings one closer to the Creator (Vasegh \& Mohammadi, 2007; Yahaya et al., 2012). Awareness of spiritual experience can be seen as a self-healing tool (West, 2004) as it has been found to have a significant relationship with health (McCauley et al., 2008). In the Malaysian context, Yahaya et al. (2012) found spiritual values to be among the resilience factors facilitating students' coping with their physiological and physical changes. 
Man's relationship with the natural environment makes him aware of and connected with something greater than himself (referring to the Creator as God) and can provide a sense of emotional healing (Sempik et al., 2010). d'Souza (2017) emphasises that activities conducted in the garden (such as praying, meditation, thinking, pondering, and appreciating the natural environment) can improve psychological well-being.

\section{METHODS AND AIMS}

To conduct the systematic review, we searched for articles based on the following criteria: (a) concerning the relationship between ecopsychology and emotional disturbance (stress, anxiety and depression; (b) the articles were published in peer-reviewed journals; (c) indexed by the Social Sciences Citation Index (SSCI) or the Science Citation Index Expanded (SCIE); and (d) presented studies in the areas of environmental psychology, education, social and behavioural sciences. The researchers sought articles relating to people's exposure, connectedness, and engagement with the natural environment and health within the educational context. The databases searched included: ISI Web of Science, Scopus and Google Scholar Search (Haddaway et al., 2018). Our selection was not limited by the year of publication. The articles were searched using the combination of the following keywords: "ecopsychology", "restorativeness", or "spiritual values" with one of the following terms: "students", "nature", "stress", "anxiety", and "depression".

During the review process, the researchers focused on the following matters:

1. Emotional well-being and its association with the natural environment

2. The nature of the data collected, whether experimental, self-reported data, qualitative or other data sources

3. The research design, level of analysis, and sampling techniques or participant selection method.

The research questions of this study focused on identifying the research gaps in the current methods and strategies (Miles, 2017). The strategies adopted in previous studies mainly focus on shreds of evidence, theoretical aspects, methodology interest, populations, and results. These gaps motivated our focus on examining the level of ecopsychology among youth who have limited access to nature and green space and prefer indoor activities instead (Nabilla et al., 2018). Frumkin et al., (2017) in their paper review published questions on potential doubts that may arise if people who walk in natural settings evince lower levels of stress than those who do not: Is that because the nature contact has a salutary effect, or is it because people who are better at managing their stress choose to take more nature walks? This study proposed a conceptual framework based on the reviewed studies with the aim of guiding future work on using the natural environment to reduce emotional disturbances among students. 


\section{RESULTS AND DISCUSSION}

Our first research objective was to identify the relationship between (i) various facets of exposure to the natural environment and (ii) various psychological health-related variables. Towards this end, this study proposed a conceptual framework (Fig. 2) comprising of related variables as identified from the literature review. The variables relate to the significant relationship between exposure to nature and psychological well-being (both positive and negative emotions) (Park et al., 2011, Song et al., 2014). Other scholars (Frumkin et al. 2017; Sandifer et al. 2015) have also highlighted the psychological, cognitive, physiological, social connection, spirituality, and cultural benefits of nature.

Another meta-analysis review also described the effect size in the nature exposure with experimental manipulation of nature vs urban applying video and photographs indicated there was a significant effect (Dopko, 2012; Weinstein et al., 2009). Most of the studies focused on pre-and post-test experimental exercises in green and urban environments. The exercises included walking, cycling, running, camping, gardening (Herzog et al., 2003; Frumkin, 2001) as well as other passive activities, such as viewing nature through a window or painting (Benfield et al., 2015; Kuo \& Sullivan, 2001, Ulrich, 1984). These studies specifically measured health outcomes by assessing participants' salivary cortisol levels, heart rate (using EEG methods), and brain imaging activities (Bratman et al., 2015; Jiang et al., 2014; Tilley et al., 2017). The participants were assessed using psychological measurements, such as Depression, Anxiety and Stress Scale (DASS), Profile of Moods (POMS), Psychological Well-being (PWB) and State-Trait Anxiety Inventory (STAI) to rate how nature had helped them elucidate emotional disturbances.

Most previous studies have examined the effects of exposure to nature (and other elements related to nature) on emotional disturbance and psychological well-being. Some of the studies found that such a relationship was mediated by specific mediators, such as restorativeness and spiritual values (Kamitsis \& Francis, 2013). Exposure to nature was found to (i) create a connection for feeling calm, relaxed, and happy and (ii) promote self-restoration from mental fatigue, hence restoring focus capacity and reducing stress (Bell, 2012; Hartig, 2003; Kaplan, 1995; Kaplan \& Kaplan, 1989; Van den Berg et al., 2014). In contrast, an urban or artificial environment has increased emotional distress (Hartig et al., 1997; Kaplan \& Kaplan, 1989; Laumann et al., 2001; Tyrväinen et al., 2014). This evidence reinforces the notion that nature can create harmony and reduce emotional disturbance.

Previous researchers in ecology have found an emotional connection between nature and well-being through the element of spirituality (Baillie, 2003; Fox, 2000; Roszak, 1992; Roszak et al., 1995). Correspondingly, other scholars (Kamitsis \& Francis, 2013; Trigwell et al. 2014) discovered the significant effect of nature on participants' psychological well-being. These findings affirmed the importance of nature for eco psychological relations, restoration, spiritual values and human emotions.

Thus, this research intends to examine how the effects of ecopsychology unfold on participants' stress, anxiety, and depressive emotion. This study proposed a model of 
ecopsychology effect on emotional disturbance (Fig. 2) to validate the relationships among the variables examined in previous studies. In doing so, the researcher established restorativeness and spiritual values as mediators between ecopsychology and emotional disturbance.

In this review, an attempt was made to compare and contrast the findings of previous studies that employed different data sources and research designs. Results show that qualitative and experimental designs on the direct relationship between ecopsychology, restorativeness, and spiritual values and human health in the Natural environment are well documented (Sandifer et al., 2015). However, further investigation is needed to enhance rich research findings by adding new variables to be tested in the existing model (Kamitsis \& Francis, 2013).

This study also identified that most of the previous studies derived findings based on significant relationships and effect sizes (Pritchard et al., 2020). The studies used crosssectional of the self-reported method in assessing the level and causal relationship between variables, which raises concern on common method bias (CMB) (Podsakoff et al., 2003). One of the solutions is applying Harman's single-factor analysis method to conduct exploratory factor analysis to ensure there is no serious bias in the items (Fuller et al., 2016; Schaller et al., 2015).

\section{Proposed Conceptual Framework}

This study proposed that the conceptual framework (Fig. 2) be tested to explain the relationships among the proposed variables. The variables were established from the theoretical background and previous models (Kamitsis \& Francis, 2013; Marselle et al., 2016). Kamitsis and Francis (2013) assessed spiritual values as the mediator between connectedness to nature and psychological well-being. Marselle et al. (2016) recommended perceived restorativeness to comprise being away, fascination, compatibility, and coherence as mediators between certain predictor variables (perceived naturalness, perceived biodiversity, walk duration, and perceived walk intensity) and post-walk emotional well-being. Both models will be tested to investigate the link between emotional connection in a Natural environment and the lessening of negative emotions and improvement of psychological well-being.

Reviewed studies have also indicated that there is a direct relationship between all the variables, with restorativeness and spiritual values acting as mediators between ecopsychology and emotional disturbance in the natural environment. The model proposed (Fig. 2) is a continuation of the previous theoretical foundation supported by the proposed Eco-Spiritual Helping Model (ESH), which aims to improve psychological health with a spiritual dimension (Besthorn et al., 2010). 


\section{Figure 2}

\section{Proposed Conceptual Framework}

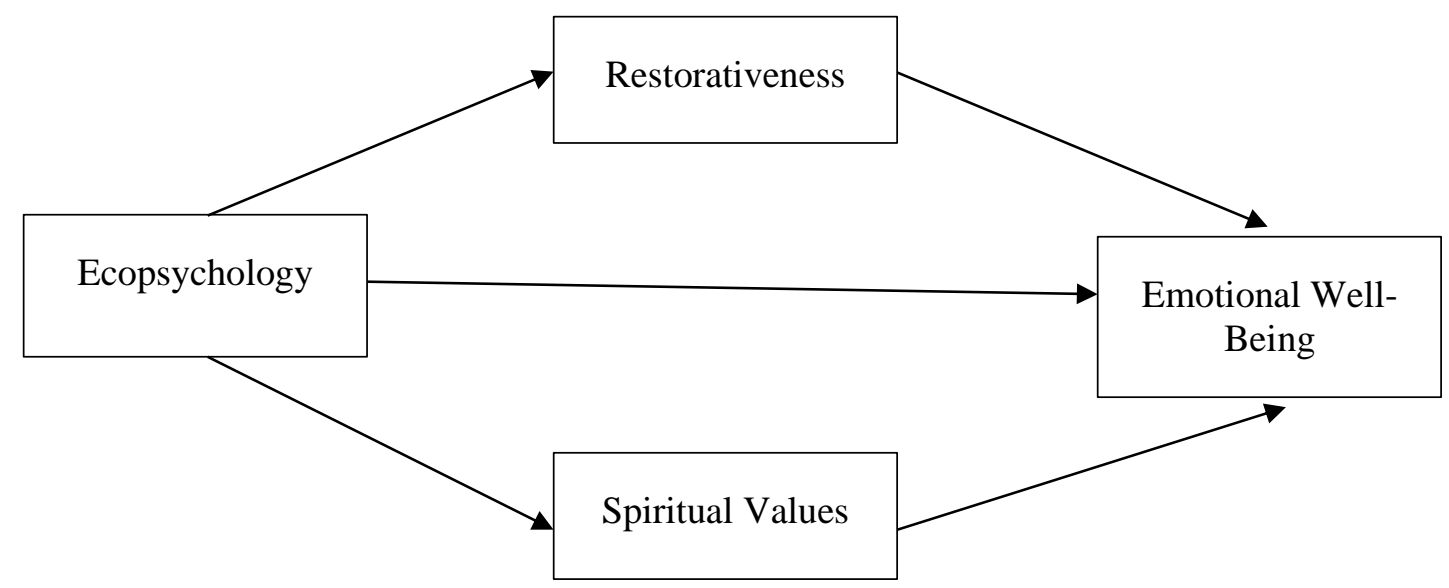

The present review examined the extant literature on the relationship between exposure to nature and reduced emotional disturbance and improved psychological well-being. The focuses of the study are on (i) the relationship between the different facets of exposure to Natural environment and different health-related variables and (ii) the differences, to date, collectively past studies based on research design and strategies employed.

The association between ecopsychology and emotional disturbance in a Natural environment is supported mainly by the previous studies. These studies, however, mainly focused on positive and negative emotions. Due to the increasing numbers of stress, anxiety and depression cases globally, further study must uncover how the ecopsychology concept lessens emotional disturbance. The present review also discusses the knowledge, theoretical underpinning, methodological and population strategies concerning the subject matter.

\section{Knowledge and Evidence Gaps}

Generally, a nature-based environment is claimed to have restoration elements. Studies in a nature setting (Annerstedt et al., 2013; Barton et al., 2012) found that green or blue (water) areas not only pertain to plant types but also to seasons and areas (Mackay \& Neill, 2010), playgrounds (Van Herzele \& de Vries; 2012), small gardens or arboretum (Adevi \& Martensson, 2013; Berman et al., 2008), forests (Annerstedt et al., 2013; Berger \& Tiry, 2012), parks or green areas on the road (van Dillen et al., 2012), beaches (White et al., 2010; Wyles et al., 2014) aquarium (Cracknell et al., 2016); mountains and forests (Berman et al., 2008), wildlife protection (Bird, 2004), and undeveloped landscapes. Such diversity offers a salutogenic concept in promoting the value of health (Antonovsky, 1979). Therefore, environmental restoration can be said to be able to reduce the stress load experienced by individuals.

Thus, nature can significantly reduce stress (Ulrich et al., 2004). The direct linkage between emotional well-being and health has been proven (Sandifer et al., 2015). Some of the previous studies have assessed the relationship between nature exposure and physical disease. 
In one study in New Zealand, Richardson et al. (2010) found no evidence that nature influences the mortality of patients with the cardiovascular disease despite other studies attesting the association between a nature-based environment and health benefits.

The phenomenon of nature deficit disorder, particularly among children (Louv, 2008), seems to be more apparent in the era of urbanisation. The contributing factors are (1) obsession with the internet and gadget (the time spent recorded was 6.5 hours per day on average) (Roberts \& Foehr, 2008); (2) parental concern over the safety of children playing outside (Brussoni et al., 2012; Kellert, 2005); (3) crime cases in parks or outdoors particularly among women (Boomsma \& Steg, 2014; Stodolska et al., 2013); (4) changes in weather, haze, temperature, and environmental pollution (de Montigny et al. 2012); and (5) perceptions through social and cultural norms (Schultz et al., 2014). These factors will significantly impact visitation to nature (Wan et al., 2020) and evoke (i) uneasy feeling (Jarrell et al., 2013; Sreetheran \& van den Bosch, 2014) and (ii) hesitation in allowing children to engage in physical activities outdoor and interaction with nature (Freudenberg \& Arlinghaus, 2009; von Benzon, 2011). Therefore, accumulative concerns regarding nature deficit disorder need to be taken seriously to change individual attitudes, behaviours, and perceived benefits, thereby influencing their visit to urban parks (Wan et al., 2020). Being more pro-environmental promotes the nature space for human health and well-being as the central purpose of urban planning and interaction with nature (Barton et al., 2009).

\section{Theoretical Gaps - Underpinning Theory}

Bettering mental health has become challenging. Lazarus and Folkman (1989) stated that stress is experienced when a person perceives that the 'demands exceed the personal and social resources the individual can mobilise.' This notion is called the 'transactional model of stress and coping.' Neither the environmental event nor the person's response defines stress; instead, the individual's perception of the psychological situation is critical. The effects stress has on a person are based more on their personal feelings of threat, vulnerability, and ability to cope than on the stressful event itself. Lazarus and Folkman also define stress as a particular relationship between the person and environment that the person appraises as exceeding their resources and endangering their well-being. The most common symptoms experienced by those frequently attacked by overstressing are categorized into behaviour (productivity and absence), physiological (diseases such as dizziness, nausea, hypertension) and psychological (anxiety and depression). Thus, having stress, anxiety, and depression in a more prolonged and continuous period has been shown to have harmful effects; it often results in one body's need to return to homeostatic conditions by releasing hormones and other chemicals to restore the prestress conditions. Biological changes due to stress include (a) increased stress hormones like catecholamines, corticotropin-releasing hormone, serotonin, neuropeptide Y, cortisol, and glucagon; (b) impaired immune function, such as reduced white blood cell count, reduced Tcell activity; (c) increased risk of chronic diseases like cardiovascular disease, diabetes and cancer; and (d) increased oxidative stress markers like thiobarbituric acid reactive species (TBARS) (Cohen et al., 2007; Kawaguchi et al., 2007). 
Kaplan and Kaplan (1989) and Ulrich et al. (1991) publicised the Attention Restorative Theory (ART) and Stress Recovery Theory (SRT) theories to (i) relate the malfunction of the unique effect of mental health issues and (ii) promote Natural environment as nonclinical efforts to reduce emotional disturbance in particularly stress. They assert that concentration improved after one spent time in nature, or even looked at the scenes of nature. ART also describes the conditions that promote recovery from mental fatigue. These conditions, which are found in restorative settings, are characterised by

1. being away (temporary escape from one's usual setting or situation);

2. extent (a sense of being part of a larger whole);

3. fascination (an involuntary form of attention requiring effortless interest or curiosity); and

4. compatibility (a setting that satisfies the individual's purposes).

Past research has shown that attention is categorised into two components: involuntary attention and voluntary directed attention (Kaplan \& Berman, 2017). Involuntary attention is captured by inherently intriguing or essential stimuli, whereas voluntary or directed attention is directed by a cognitive-control process (Kaplan, 1995). To support this, SRT focuses on all aspects of stress; "mental, emotional and physiological" (Wilson, 2007, p.15). The intuitivelybased beliefs that exposures to trees, water, and other nature foster psychological well-being and produce restoration from the stress of everyday urban living (Ulrich et al., 1991).

Both theories predict that the natural environment can offer a high restoration effect compared to modern urban or man-built environments. However, scholars have debated that restorativeness can occur anywhere if individuals feel attracted and comfortable with the living environment (Hartig et al., 2003). Some of the empirical findings concur that the impact of restoration is high in nature or green spaces compared to artificial or urban areas (Benfield et al., 2015; Ulrich et al., 1991).

The term ecopsychology was introduced in 1990, and it emphasises emotional connection towards nature (Roszak, 1992, Roszak et al., 1995). Before it is instituted, Kellert and Wilson (1995) recommended Hypothesis Biophilia on human emotions with other living organisms (e.g., plants, vegetation, water element, and animals) related to physical, psychological, and spiritual focusing on life processes. This assumption refers to human, aesthetic, intellectual, cognitive, and spiritual aspects of restoration response in nature. In contrast, it was found that the natural environment can be substituted by a man-built environment, which is supplemented with modern technology, such as the internet and gadget for the need for more convenience (Fisher, 2006). For this reason, rapid urbanisation is said to affect the proximity of green spaces, hence upsetting mental health psychologically and even physically. The manifestation of lack of Vitamin "N" (N refers to Nature) resulted in one's emotional disconnection, which is likely to lead to disengagement of relationship with nature (Louv, 2011).

Eco psychological approaches are critical for psychological and spiritual healing. The approaches can reduce emotional disturbance associated with the natural environment (Fisher, 2013). Such connection is explained based on the broad understanding of how emotional 
connection to nature is related explicitly to human mental health. The natural environment allows restorative effects and indirectly promotes perceived human behaviour and interaction towards conservation and ecological bonds in the environmental (Roszak, 1992).

This study identified an apparent theoretical gap in the prior research concerning natural environment studies. The ecopsychology theory is dated while current studies have focused more on ART and SRT to study emotional disturbances. Some of the prior theories appear to be essential for understanding nature-based experiences. However, an investigation in terms of restorativeness and spiritual values at once to connect theoretical development is warranted. Thus, the researcher recommends an integrated theoretical framework comprising the ART (Kaplan \& Kaplan, 1989) and the SRT (Ulrich et al., 1991). These preferred theories emphasise the aspect of psychological resources that can reduce emotional disturbances. However, the studies conducted to relate the natural environment towards psychological well-being and health are rarely associated with ecopsychology theory (Roszak, 1992) and spirituality on wellbeing (Fisher, 2013). Past studies have revealed the elements of deep emotional connection, a sensation of restorativeness, mystical experiences, and feeling of oneness, or more profound connection with the Creator as part of spirituality obligation (Garfield et al., 2014; Scopelliti et al., 2019). Therefore, this study proposes using these theories to clarify the relationship between the variables studied and the lessening of emotional disturbances.

\section{Methodological Gaps}

Overall, the experimental pre-post design was the prevailing method for studying the use of the natural environment for health purposes. The challenges of using the experimental design include cost and time constraints in securing the sample to be studied. Researchers need to observe details and identify all the confounding factors, reverse causation, and possible effect or biased results. The experimental pre-post design method managed to identify how human biological markers of stress indicate the far-reaching effects of stress and its detrimental effects on long-term health (Lee et al., 2015; Schneiderman et al., 2005; Tsunetsugu et al., 2007).

On the other hand, the qualitative approach has also been employed in a good number of studies. Qualitative studies enable us to understand why people think, feel, react, and behave the way they do as we assess lived experiences (Creswell, 2008; Miles \& Huberman, 1994). Previous studies have also explored how nature-based experiences are connected to the human psychological aspect (Unruh \& Hutchinsin, 2011). Another study by Miranda (2007) investigated how nature creates human motivation from the perspective of ecopsychology.

Given the various research designs, Chalquist (2009) suggests the nature-based environment as one method of "ecotherapy." This approach is an aid to provide psychological, mental, and spiritual experience by taking outdoor activities and exposing oneself to nature. The method, in turn, creates "nature-connectedness to reduce emotional disturbance and positive relationship to increase psychological well-being" (Kamitsis \& Francis, 2013). Similarly, Heintzman (2007) found that activities such as kayaking and lighting a bonfire in the forest sparked a sense of unity with nature and the feeling of God's existence. This finding indicates that the themes of experiences in a natural environment can fulfil one's spiritual needs. 
The studies were also emphasized commemorating God, who created this earth as a more positive emotion and the sadness of one's disconnection from nature (Hegarty, 2010).

A few studies used a mixed-method in studying the relationship between nature exposure and mental health (Jakubec et al., 2016). One study conducted online $(n=118)$ through interviews $(\mathrm{n}=15)$ found that the respondents agreed that a park provides physical comfort (91\%), emotional relief space (92\%), and spiritual sense (93\%). The majority of the study participants were found to have similar views and feelings about nature's offer to the self. They believed that nature could provide psychological well-being in general.

To disentangle the methodology gaps, Müller-Bloch and Kranz (2014) also advocated using various research methods. Thus, this study seeks to extend the use of the research method specifically for data analysis. We suggest that the proposed framework be tested in different demographics and locations. Growing initiative research design conducted a proposed conceptual model framework supplement with mediator studies (Kamitsis \& Francis, 2013; Marselle et al., 2016; Trigwell et al., 2014). They found that restorativeness and spiritual values strongly connect the nature-based environment with psychological and emotional well-being (Ryff \& Keyes, 1995).

\section{Population Categories Gap}

The studies reviewed here were conducted on a wide range of diverse populations. Despite the consistent findings, Huynh et al. (2013) reported a weak connection between nature and emotional well-being. They claimed that results from the previous studies might be influenced by other factors, such as demographic characteristics, family affluence, perception of neighbourhood surroundings. Perhaps, the sampled participants were among the young generation keen to participate in different activities, such as social activities via media technology and the internet (Hasan, 2019). Even outdoor physical activities such as jogging, running, yoga, and other fitness exercises can be done indoors in a gym or health centre (Plante et al., 2007; Thompson Coon et al., 2011). In explaining such contrasting results, Barton and Pretty (2010) claimed that the relationship between nature and emotional well-being has not been explicitly studied and remains unclear concerning the youth populations. Additionally, Mitchell (2013) reported that exercise in the green space has short and long-term positive effects on mood and mental health.

Table 1 lists the previous studies focusing on undergraduate students. The majority of the studies compared the natural environment and urban living to test the students' positive and negative emotions. The sampled students were tested in an intervention setting; they were required to watch a green landscape video, view still photos of nature, and walk in the forest (Berman et al., 2008; Valtchanov et al., 2010; Zelenski et al., 2015). A salivary amylase test (Yamaguchi et al., 2006) was used to test the students' stress levels and examine their feelings on happiness, calmness, anger, tension, and energy (Plante et al., 2006; Hartig et al., 1991). Urban busting living might increase tension, stress, and distractions, Wells and Evans (200) reported that children $(n=12)$ with low family background income showed significant 
improvement in their directed attention and academic performance. Spending time in nature could alleviate their mental fatigue due to impulsiveness, impatience, and irritability (Berman et al., 2008; Cimprich \& Ronis, 2003; Hartig et al., 1991).

Table 1 shows previous studies investigating the mediator and moderator relationship between nature-connectedness and mental health involving undergraduate students. Howell et al. (2011) suggested (i) nature-connectedness, (ii) social, emotional, and psychological wellbeing, and (iii) degree of mindfulness (moment-to-moment awareness) as possible mediators and moderators to explain the association between nature and well-being. More studies had been conducted on nature exposure and connectedness. The studies focused primarily on restorativeness and spirituality as mediators to lessen the emotional disturbances in a Natural environment (Katmisis \& Francis, 2013; Trigwell et al., 2014). However, the findings are yet to be tested among undergraduate students. Little research has been conducted to test these mediators and examine the relationship between ecopsychology and emotional disturbances (stress, anxiety, and depression).

\section{Table 1}

List of Studies among Undergraduate Students and Nature-based Environment

\begin{tabular}{|c|c|c|c|}
\hline No. & Authors & Sample & Research \\
\hline 1. & $\begin{array}{l}\text { Zelenski et } \\
\text { al., (2015) }\end{array}$ & $\begin{array}{l}250 \text { undergraduate } \\
\text { students }\end{array}$ & $\begin{array}{l}\text { Group of participants assigned to watch nature } \\
\text { video and architectural video to examine mood } \\
\text { and positive and negative affect }\end{array}$ \\
\hline 2. & $\begin{array}{l}\text { Mao et al., } \\
(2012)\end{array}$ & $\begin{array}{l}20 \text { healthy male } \\
\text { university students }\end{array}$ & $\begin{array}{l}\text { Participants assigned to the forest walks } \\
\text { experienced improved mood and reduced levels } \\
\text { of stress and inflammatory biomarkers in } \\
\text { comparison to the urban walkers }\end{array}$ \\
\hline 3. & $\begin{array}{l}\text { Howell et } \\
\text { al., (2011) }\end{array}$ & $\begin{array}{l}452 \text { introductory } \\
\text { psychology students }\end{array}$ & $\begin{array}{l}\text { To examine moderators and mediators of the } \\
\text { relationship between nature connectedness, } \\
\text { well-being and mindfulness }\end{array}$ \\
\hline 4. & $\begin{array}{l}\text { Thompson } \\
\text { Coon et al., } \\
(2011)\end{array}$ & $\begin{array}{l}11 \text { studies (with } \\
\text { individual sample } \\
\text { sizes ranging from } 8 \\
\text { to } 269 ; 6 \text { solely } \\
\text { university students) }\end{array}$ & $\begin{array}{l}\text { To examine the positive effect of walking } \\
\text { outdoors on mood, including improvements in } \\
\text { feelings of self-esteem, energy, and vitality and } \\
\text { reductions in feelings of depression, tension, } \\
\text { frustration, or concern }\end{array}$ \\
\hline 5. & $\begin{array}{l}\text { Valtchanov } \\
\text { et al., } \\
(2010)\end{array}$ & $\begin{array}{l}22 \text { university } \\
\text { students }\end{array}$ & $\begin{array}{l}\text { To access natural views significantly improved } \\
\text { participants' moods, with no changes seen } \\
\text { among participants who viewed the images of } \\
\text { abstract paintings }\end{array}$ \\
\hline 6. & $\begin{array}{l}\text { Mayer et } \\
\text { al., (2008) }\end{array}$ & $\begin{array}{l}76 \text { undergraduate } \\
\text { psychology students }\end{array}$ & $\begin{array}{l}\text { To examine connectedness to nature strongly } \\
\text { predicts the relationship between experiences } \\
\text { with nature and emotional well-being }\end{array}$ \\
\hline
\end{tabular}




\section{Table 1}

\section{Continued}

\begin{tabular}{|c|c|c|c|}
\hline No. & Authors & Sample & Research \\
\hline 7. & $\begin{array}{l}\text { Saroglou, } \\
\text { Buxant \& } \\
\text { Tilquin } \\
(2008)\end{array}$ & $\begin{array}{l}87 \text { psychology } \\
\text { students }\end{array}$ & $\begin{array}{l}\text { To exhibit videos showing panoramic views of } \\
\text { natural landscapes, increased reported levels of } \\
\text { spirituality }\end{array}$ \\
\hline 8. & $\begin{array}{l}\text { Berman et } \\
\text { al., (2008) }\end{array}$ & $\begin{array}{l}50 \text { university } \\
\text { students }\end{array}$ & $\begin{array}{l}\text { To allow participants walking in nature } \\
\text { experienced improvements in directed attention } \\
\text { and mood, while those walking in urban settings } \\
\text { did not and to view images of nature improved } \\
\text { directed and executive attention }\end{array}$ \\
\hline 9. & $\begin{array}{l}\text { Tsunetsugu } \\
\text { et al., } \\
(2007)\end{array}$ & $\begin{array}{l}12 \text { male university } \\
\text { students }\end{array}$ & $\begin{array}{l}\text { To access stress levels were lower following the } \\
15 \text {-minute walk in the forest than in the urban } \\
\text { setting; the forest walk also produced feelings of } \\
\text { comfort, calm and refreshment }\end{array}$ \\
\hline 10. & $\begin{array}{l}\text { Plante et } \\
\text { al., (2007) }\end{array}$ & $\begin{array}{l}88 \text { female } \\
\text { undergraduate } \\
\text { students aged } 18 \text { to } \\
22 \text { years old }\end{array}$ & $\begin{array}{l}\text { To examine the level of AD-ACL (energy, } \\
\text { calmness, tension, tiredness) and PACES } \\
\text { (physical activity enjoyment) in the nature } \\
\text { environment }\end{array}$ \\
\hline 11. & $\begin{array}{l}\text { Yamaguchi } \\
\text { et al., } \\
(2006)\end{array}$ & $\begin{array}{l}10 \text { male university } \\
\text { students }\end{array}$ & $\begin{array}{l}\text { To access stress level using salivary amylase } \\
\text { test }\end{array}$ \\
\hline 12. & $\begin{array}{l}\text { Plante et } \\
\text { al., (2006) }\end{array}$ & $\begin{array}{l}112(47 \text { male and } 65 \\
\text { female) psychology } \\
\text { students }\end{array}$ & $\begin{array}{l}\text { To examine level of AD-ACL (energy, } \\
\text { calmness, tension, tiredness), PACES (physical } \\
\text { activity enjoyment) and Marlowe Crowne Social } \\
\text { Desirability Scale) in the Natural environment }\end{array}$ \\
\hline 13. & $\begin{array}{l}\text { Hartig et } \\
\text { al., (1991) }\end{array}$ & $\begin{array}{l}34 \text { college students } \\
(17 \text { men, } 17 \text { women })\end{array}$ & $\begin{array}{l}\text { To examine level ZIPERS (fear, } \\
\text { anger/aggression, sadness, positive affect, } \\
\text { attentiveness) and Overall Happiness Scale } \\
\text { Attention (proof-reading task) on the level of } \\
\text { restorativeness }\end{array}$ \\
\hline
\end{tabular}




\section{CONCLUSION}

This review provides a way of understanding the relationship between Natural environment relatedness and emotional well-being, particularly across different data sources, research designs, and levels of analysis. The study observed that most studies included the elements of exposure, connectedness, and engagement towards nature in lessening emotional disturbance and improving psychological well-being throughout the review process. Some studies have designed models of restorativeness by adding the effects of spiritual values concerning Natural environment relationships. Despite such fundamental understanding, the impact might be different across demographical and geographical climates. This study proposed that more advanced and varied research techniques be applied to improve our current theoretical framework, including examining the possible reciprocal relationship between ecopsychology and emotional well-being. This study also recommends that more research be conducted in newly developed countries to address more proximity to the Natural environment and emotional well-being. Additionally, Islamic perspective also emphasizes on the appreciation and being connected to since this strengthens Muslims' belief (iman) and conviction in the existence of God as the Creator, which in return increases their taqwa. Finally, Muslims' play an important role as Khalifah, who have been entrusted to carry out the task to utilize, preserve and conserve the Natural environment for better human civilization and sustainable development.

The present review has a few limitations. Firstly, this study did not consider studies that measured (i) the element of "what is in nature" (such as biodiversity) and (ii) environmental quality indicators, such as perceived naturalness. The reason is that these studies could not provide an independent result on the effect of ecopsychology on emotional connection towards exposure to nature and human well-being. Next, this study limited our search to articles focusing on emotional disturbance, which comprises stress, anxiety, and depression. The researcher excluded other aspects of individual well-beings, such as psychological well-being and positive emotions.

Also, the focus of the present research is on lessening the emotional disturbance effect of undergraduate students. The study is therefore conducted at the individual level rather than at the organisational level. Thus, there may be findings that indicate the significance of personal perception, which should be interpret with caution. In addition, although this study anticipated suffering on Common Method Bias (CMB), it is highly likely that the validity of the findings will not be seriously jeopardised. Hence, the proposed research design is considered valid. Since the conceptual framework was developed based on the theoretical model of previous studies, perhaps other researchers may explore the fitness or practical implications of the framework empirically. 


\section{REFERENCES}

Adevi, A. A., \& Mårtensson, F. (2013). Stress rehabilitation through garden therapy: The garden as a place in the recovery from stress. Urban Forestry \& Urban Greening, 12(2), 230-237.

Ahmad, N., Roslan, S., Othman, S., Shukor, S. F. A., \& Bakar, A. Y. A. (2018). The validity and reliability of psychometric profile for Depression, Anxiety and Stress Scale (DASS21) Instrument among Malaysian undergraduate students. International Journal of Academic Research in Business and Social Sciences, 8(6), 812-827.

Annerstedt, M., Jönsson, P., Wallergård, M., Johansson, G., Karlson, B., Grahn, P., Hansen, Å.M. \& Währborg, P. (2013). Inducing physiological stress recovery with sounds of nature in a virtual reality forest-Results from a pilot study. Physiology \& Behavior, 118, 240-250.

Annerstedt, M., \& Währborg, P. (2011). Nature-assisted therapy: Systematic review of controlled and observational studies. Scandinavian Journal of Social Medicine, 39(4), 371-388.

Antonovsky, A. (1979). Health, stress, and coping. Jossey-Bass.

Baillie, R. (2003). Applied ecopsychology in Australia: Approaches to facilitating humannature connections. Gatherings: Seeking Ecopsychology, 8.

Barton, B. T., \& Schmitz, O. J. (2009). Experimental warming transforms multiple predator effects in a grassland food web. Ecology Letters, 12(12), 1317-1325.

Barton, J., Griffin, M., \& Pretty, J. (2012). Exercise, nature-and socially interactive-based initiatives improve mood and self-esteem in the clinical population. Perspectives in Public Health, 132(2), 89-96

Barton, J., \& Pretty, J. (2010). What is the best dose of nature and green exercise for improving mental health? A multi-study analysis. Environmental Science \& Technology, 44(10), 3947-3955.

Bell, S. (2012). Landscape: pattern, perception and process. Routledge.

Benfield, J. A., Rainbolt, G. N., Bell, P. A., \& Donovan, G. H. (2015). Classrooms with nature views: Evidence of differing student perceptions and behaviors. Environment and Behavior, 47(2), 140-157.

Berger, R., \& Tiry, M. (2012). The enchanting forest and the healing sand-Nature therapy with people coping with psychiatric difficulties. The Arts in Psychotherapy, 39(5), 412416.

Berman, M. G., Jonides, J., \& Kaplan, S. (2008). The cognitive benefits of interacting with nature. Psychological Science, 19(12), 1207-1212.

Besthorn, F. H., Wulff, D., \& St. George, S. (2010). Eco-spiritual helping and postmodern therapy: A deeper ecological framework. Ecopsychology, 2(1), 23-32. 
Bird, W. (2004). Natural Fit: Can green space and biodiversity increase levels of physical activity. A report for Royal Society for the Protection of Birds. RSPB.

Boomsma, C., \& Steg, L. (2014). The effect of information and values on acceptability of reduced street lighting. Journal of Environmental Psychology, 39, 22-31.

Bratman, G. N., Hamilton, J. P., Hahn, K. S., Daily, G. C., \& Gross, J. J. (2015). Nature experience reduces rumination and subgenual prefrontal cortex activation. Proceedings of the national academy of sciences, 112(28), 8567-8572.

Brussoni, M., Olsen, L. L., Pike, I., \& Sleet, D. A. (2012). Risky play and children's safety: Balancing priorities for optimal child development. International Journal of Environmental Research and Public Health, 9(9), 3134-3148.

Chalquist, C. (2009). A look at the ecotherapy research evidence. Ecopsychology, 1(2), 64-74.

Cimprich, B., \& Ronis, D. L. (2003). An environmental intervention to restore attention in women with newly diagnosed breast cancer. Cancer Nursing, 26(4), 284-292.

Cohen, S., Janicki-Deverts, D., \& Miller, G. E. (2007). Psychological stress and disease. Jama, 298(14), 1685-1687.

Cracknell, D., White, M. P., Pahl, S., Nichols, W. J., \& Depledge, M. H. (2016). Marine biota and psychological well-being: A preliminary examination of dose-response effects in an aquarium setting. Environment and Behavior, 48(10), 1242-1269.

Creswell, J. W. (2008). Educational research. Planning, conducting, and evaluating quantitative and qualitative research. ( $\left.3^{\text {rd }} \mathrm{ed}\right)$. Pearson/Merrill Prentice Hall.

d'Souza, S. (2017). Gardening as a source of spiritual capital. In Spiritual Capital (pp. 159170). Gower.

de Montigny, L., Ling, R., \& Zacharias, J. (2012). The effects of weather on walking rates in nine cities. Environment and Behavior, 44(6), 821-840.

Dopko, R. L. (2012). Effects of nature on cooperation in a common dilemma: Implications for sustainability [Doctoral dissertation]. Carleton University.

Downs. M., \& Eisenbery, D. (2012), Help seeking and treatment use among suicidal college students. Journal of American College Health, 60 (2), 104 - 113.

Fisher, A. (2013). Ecopsychology at the crossroads: Contesting the nature of a field. Ecopsychology, 5(3), 167-176.

Fisher, T. (2006). Educational transformation: Is it, like 'beauty', in the eye of the beholder, or will we know it when we see it? Education and Information Technologies, 11(3-4), 293303.

Fox, M. (2000). Passion for creation: The earth-honoring spirituality of Meister Eckhart. Simon and Schuster.

Franken, C., (1994). The role of positive emotions in positive psychology: The broadening and build theory of positive emotions. American Psychologist, 56, 218-226. 
Freudenberg, P., \& Arlinghaus, R. (2009). Benefits and constraints of outdoor recreation for people with physical disabilities: inferences from recreational fishing. Leisure Sciences, 32(1), 55-71.

Frumkin, H. (2001). Beyond toxicity: human health and the natural environment. American Journal of Preventive Medicine, 20(3), 234-240.

Frumkin, H., Bratman, G. N., Breslow, S. J., Cochran, B., Kahn, P. H., Lawler, J. J., Levin, P.S., Tandon, P.S., Varanasi, U., Wolf, K.L., \& Wood, S. A. (2017). Nature contact and human health: A research agenda. Environmental Health Perspectives, 125(7), 0750011.

Garfield, A. M., Drwecki, B. B., Moore, C. F., Kortenkamp, K. V., \& Gracz, M. D. (2014). The Oneness Beliefs Scale: Connecting spirituality with pro-environmental behavior. Journal for the Scientific Study of Religion, 53(2), 356-372.

Haddaway, N.R., Macura, B., Whaley, P., et al., (2018). Reporting standards for Systematic Evidence Syntheses: pro forma, flow-diagram and descriptive summary of the plan and conduct of environmental systematic reviews and systematic maps. Environmental Evidence, 7(1), 1-8.

Hartig, T., Evans, G. W., Jamner, L. D., Davis, D. S., \& Gärling, T. (2003). Tracking restoration in natural and urban field settings. Journal of Environmental Psychology, 23(2), 109-123.

Hartig, T., Kaiser, F. G., \& Bowler, P. A. (2001). Psychological restoration in nature as a positive motivation for ecological behavior. Environment and Behavior, 33(4), 590-607.

Hartig, T., Korpela, K., Evans, G. W., \& Gärling, T. (1997). A measure of restorative quality in environments. Scandinavian Housing and Planning Research, 14(4), 175-194.

Hartig, T., Mang, M., \& Evans, G. W. (1991). Restorative effects of natural environment experiences. Environment and Behavior, 23(1), 3-26.

Hartig, T., \& Staats, H. (2006). The need for psychological restoration as a determinant of environmental preferences. Journal of Environmental Psychology, 26(3), 215-226.

Hasan, A. A. H. (2019). Prevalence of internet addiction, its association with psychological distress, coping strategies among undergraduate students. Nurse Education Today, 81, 78-82.

Hegarty, J. R. (2010). Out of the consulting room and into the woods? Experiences of natureconnectedness and self-healing. European Journal of Ecopsychology, 1, 64-84.

Heintzman, P. (2007). Men's wilderness experience and spirituality: A qualitative study. In Burns, R.; Robinson, K., comps. Proceedings of the 2006 Northeastern Recreation Research Symposium (Vol. 14). Gen. Tech. Rep. NRS-P-14. (pp. 216-225). Department of Agriculture, Forest Service, Northern Research Station.

Herzog, T. R., Maguire, P., \& Nebel, M. B. (2003). Assessing the restorative components of environments. Journal of Environmental Psychology, 23(2), 159-170. 
Howell, A. J., Dopko, R. L., Passmore, H. A., \& Buro, K. (2011). Nature connectedness: Associations with well-being and mindfulness. Personality and Individual Differences, 51(2), 166-171.

Huynh, Q., Craig, W., Janssen, I., \& Pickett, W. (2013). Exposure to public natural space as a protective factor for emotional well-being among young people in Canada. BMC Public Health, 13(1), 407.

Jakubec, S. L., Den Hoed, D. C., Krishnamurthy, A., Ray, H., \& Quinn, M. (2016). P015 Nature Teaches Us to Grieve: The Place of Parks and Nature at End of Life. Journal of Pain and Symptom Management, 52(6), 69.

Jarrell, M. L., Lynch, M., Stretesky, P. B., Arrigo, B., \& Bersot, H. (2013). Green criminology and green victimization. The Routledge handbook of international crime and justice studies. (pp. 423-444). Routledge.

Jiang, B., Chang, C. Y., \& Sullivan, W. C. (2014). A dose of nature: Tree cover, stress reduction, and gender differences. Landscape and Urban Planning, 132, 26-36.

Kamitsis, I., \& Francis, A. J. (2013). Spirituality mediates the relationship between engagement with nature and psychological well-being. Journal of Environmental Psychology, 36, 136-143.

Kaplan, R., \& Kaplan, S. (1989). The experience of nature: A psychological perspective. CUP Archive.

Kaplan, S. (1995). The restorative benefits of nature: Toward an integrative framework. Journal of Environmental Psychology, 15(3), 169-182.

Kaplan, S., \& Berman, M. G. (2010). Directed attention as a common resource for executive functioning and self-regulation. Perspectives on Psychological Science, 5(1), 43-57.

Kawaguchi, Y., Toyomasu, K., Yoshida, N., Baba, K., Uemoto, M., \& Minota, S. (2007). Measuring job stress among hospital nurses: an attempt to identify biological markers. Fukuoka igaku zasshi = Hukuoka acta medica, 98(2), 48-55.

Kellert, S. R. (2005). Nature and childhood development. Building for life: Designing and understanding the human-nature connection, 63-89.

Kellert, S. R., \& Wilson, E. O. (Eds.). (1995). The biophilia hypothesis. Island Press. Washington, DC.

Kuo, F. E., \& Sullivan, W. C. (2001). Environment and crime in the inner city: Does vegetation reduce crime? Environment and Behavior, 33(3), 343-367.

Lazarus, R. S., \& Folkman, S. (1989). Manual Hassles and Uplifts Scales: Sampler Set: Manual and Test Booklet. Mind Garden.

Laumann, K., Gärling, T., \& Stormark, K. M. (2001). Rating scale measures of restorative components of environments. Journal of Environmental Psychology, 21(1), 31-44. 
Lee, A. C. K., Jordan, H. C., \& Horsley, J. (2015). Value of urban green spaces in promoting healthy living and wellbeing: prospects for planning. Risk Management and Healthcare Policy, 8, 131.

Law, D. W. (2007). Exhaustion in university students and the effect of coursework involvement. Journal of American College Health, 55(4), 239-245.

Louv, R. (2008). Last child in the woods: Saving our children from nature-deficit disorder. Algonquin Books.

Louv, R. (2011). The nature principle. Human restoration and the end of nature-deficit disorder. (1st ed.). Algonquin Books.

Mackay, G. J., \& Neill, J. T. (2010). The effect of "green exercise" on state anxiety and the role of exercise duration, intensity, and greenness: A quasi-experimental study. Psychology of Sport and Exercise, 11(3), 238-245.

Mao, G. X., Lan, X. G., Cao, Y. B., Chen, Z. M., He, Z. H., Lv, Y. D., \& Jing, Y. A. N. (2012). Effects of short-term forest bathing on human health in a broad-leaved evergreen forest in Zhejiang Province, China. Biomedical and Environmental Sciences, 25(3), 317-324.

Marselle, M. R., Irvine, K. N., Lorenzo-Arribas, A., \& Warber, S. L. (2016). Does perceived restorativeness mediate the effects of perceived biodiversity and perceived naturalness on emotional well-being following group walks in nature? Journal of Environmental Psychology, 46, 217-232.

Mayer, F. S., Frantz, C. M., Bruehlman-Senecal, E., \& Dolliver, K. (2009). Why is nature beneficial? The role of connectedness to nature. Environment and Behavior, 41(5), 607643.

McCauley, J., Tarpley, M. J., Haaz, S., \& Bartlett, S. J. (2008). Daily spiritual experiences of older adults with and without arthritis and the relationship to health outcomes. Arthritis Care \& Research, 59(1), 122-128.

Miles, M. B., \& Huberman, A. M. (1994). Qualitative data analysis: An expanded sourcebook. SAGE.

Miles, D. A. (2017). A Taxonomy of Research Gaps: Identifying and Defining the Seven Research Gaps. In Doctoral Student Workshop: Finding Research Gaps-Research Methods and Strategies, Dallas, Texas.

Miranda, R. (2007). From instinct to domination to boundless creativity: An integrative model of human motivation from the perspective of ecopsychology and attachment theory. [Doctoral dissertation]. California Institute of Integral Studies.

Mitchell, R. (2013). Is physical activity in natural environments better for mental health than physical activity in other environments? Social Science \& Medicine, 91, 130-134.

Müller-Bloch, C., \& Kranz, J. (2014). A framework for Rigorously Identifying Research Gaps in Qualitative Literature Reviews. Proceedings of the 36th International Conference on Information Systems, Fort Worth, 1-19. 
Nabilla, N. A., Roslan, S., Ghiami, Z., \& Ahmad, N. (2018). Assessing the relationship between perceived restorativeness and psychological well-being among students. Malaysian Journal of Public Health Medicine, 18(1), 113-123.

Nisbet, E. K., Zelenski, J. M., \& Murphy, S. A. (2011). Happiness is in our nature: Exploring nature relatedness as a contributor to subjective well-being. Journal of Happiness Studies, 12(2), 303-322.

Park, B. J., Furuya, K., Kasetani, T., Takayama, N., Kagawa, T., \& Miyazaki, Y. (2011). Relationship between psychological responses and physical environments in forest settings. Landscape and Urban Planning, 102(1), 24-32.

Park, S., Lee, J., Kang, D. Y., Rhee, C. W., \& Park, B. J. (2012). Indoor physical activity reduces all-cause and cardiovascular disease mortality among elderly women. Journal of Preventive Medicine and Public Health, 45(1), 21.

Plante, T. G., Cage, C., Clements, S., \& Stover, A. (2006). Psychological benefits of exercise paired with virtual reality: Outdoor exercise energizes whereas indoor virtual exercise relaxes. International Journal of Stress Management, 13(1), 108.

Plante, T. G., Gores, C., Brecht, C., Carrow, J., Imbs, A., \& Willemsen, E. (2007). Does exercise environment enhance the psychological benefits of exercise for women? International Journal of Stress Management, 14(1), 88.

Pritchard, A., Richardson, M., Sheffield, D., \& McEwan, K. (2020). The relationship between nature connectedness and eudaimonic well-being: A meta-analysis. Journal of Happiness Studies, 21(3), 1145-1167.

Reave, L. (2005). Spiritual values and practices related to leadership effectiveness. The Leadership Quarterly, 16(5), 655-687.

Richardson, E., Pearce, J., Mitchell, R., Day, P., \& Kingham, S. (2010). The association between green space and cause-specific mortality in urban New Zealand: an ecological analysis of green space utility. BMC Public Health, 10(1), 240.

Roberts, D. F., \& Foehr, U. G. (2008). Trends in media use. The Future of Children, 18(1), 1137.

Roszak, T. (1992). The voice of the earth: An exploration of ecopsychology. Simon et Schuster.

Roszak, T. E., Gomes, M. E., \& Kanner, A. D. (1995). Ecopsychology: Restoring the earth, healing the mind. Sierra Club Books.

Ryff, C. D., \& Keyes, C. L. M. (1995). The structure of psychological well-being revisited. Journal of Personality and Social Psychology, 69(4), 719.

Said, D., Kypri, K., \& Bowman, J. (2013). Risk factors for mental disorder among university students in Australia: findings from a web-based cross-sectional survey. Social Psychiatry and Psychiatric Epidemiology, 48(6), 935-944.

Sandifer, P. A., Sutton-Grier, A. E., \& Ward, B. P. (2015). Exploring connections among nature, biodiversity, ecosystem services, and human health and well-being: Opportunities to enhance health and biodiversity conservation. Ecosystem Services, 12, 1-15. 
Saroglou, V., Buxant, C., \& Tilquin, J. (2008). Positive emotions as leading to religion and spirituality. Journal of Positive Psychology, 3(3), 165-173.

Schneiderman, N., Ironson, G., \& Siegel, S. D. (2005). Stress and health: psychological, behavioral, and biological determinants. Annual Review Clinical Psychology, 1, 607-628.

Schultz, P. W. (2014). Strategies for promoting proenvironmental behavior. European Psychologist.

Scopelliti, M., Carrus, G., \& Bonaiuto, M. (2019). Is it really nature that restores people? A comparison with historical sites with high restorative potential. Frontiers in Psychology, 9, 2742.

Sempik, J., Hine, R., \& Wilcox, D. (Eds.). (2010). Green Care: A conceptual framework: A report of the working group on health benefits of Green Care. Loughborough University.

Song, C., Ikei, H., Igarashi, M., Miwa, M., Takagaki, M., \& Miyazaki, Y. (2014). Physiological and psychological responses of young males during spring-time walks in urban parks. Journal of Physiological Anthropology, 33(1), 1-7.

Sreetheran, M., \& Van Den Bosch, C. C. K. (2014). A socio-ecological exploration of fear of crime in urban green spaces-A systematic review. Urban Forestry \& Urban Greening, 13(1), 1-18.

Stodolska, M., Shinew, K. J., Acevedo, J. C., \& Roman, C. G. (2013). “I was born in the hood”: Fear of crime, outdoor recreation and physical activity among Mexican-American urban adolescents. Leisure Sciences, 35(1), 1-15.

Thompson Coon, J., Boddy, K., Stein, K., Whear, R., Barton, J., \& Depledge, M. H. (2011). Does participating in physical activity in outdoor natural environments have a greater effect on physical and mental well-being than physical activity indoors? A systematic review. Environmental Science \& Technology, 45(5), 1761-1772.

Tilley, S., Neale, C., Patuano, A., \& Cinderby, S. (2017). Older people's experiences of mobility and mood in an urban environment: a mixed methods approach using electroencephalography (EEG) and interviews. International Journal of Environmental Research and Public Health, 14(2),151.

Trigwell, J. L., Francis, A. J., \& Bagot, K. L. (2014). Nature connectedness and eudaimonic well-being: Spirituality as a potential mediator. Ecopsychology, 6(4), 241-251.

Tsunetsugu, Y., Park, B. J., Ishii, H., Hirano, H., Kagawa, T., \& Miyazaki, Y. (2007). Physiological effects of Shinrin-yoku (taking in the atmosphere of the forest) in an oldgrowth broadleaf forest in Yamagata Prefecture, Japan. Journal of Physiological Anthropology, 26(2), 135-142.

Tyrväinen, L., Ojala, A., Korpela, K., Lanki, T., Tsunetsugu, Y., \& Kagawa, T. (2014). The influence of urban green environments on stress relief measures: A field experiment. Journal of Environmental Psychology, 38, 1-9.

Ulrich, R. (1984). View through a window may influence recovery. Science, 224 (4647), 224225. 
Ulrich, R. S., Simons, R. F., Losito, B. D., Fiorito, E., Miles, M. A., \& Zelson, M. (1991). Stress recovery during exposure to natural and urban environments. Journal of Environmental Psychology, 11(3), 201-230.

Ulrich, R., Zimring, C., Quan, X., Joseph, A., \& Choudhary, R. (2004). The role of the physical environment in the hospital of the 21st century. The Center for Health Design.

Unruh, A., \& Hutchinson, S. (2011). Embedded spirituality: gardening in daily life and stressful life experiences. Scandinavian Journal of Caring Sciences, 25(3), 567-574.

Valtchanov, D. (2010). Physiological and affective responses to immersion in virtual reality: Effects of nature and urban settings. [Master Thesis). University of Waterloo.

Van den Berg, A. E., Jorgensen, A., \& Wilson, E. R. (2014). Evaluating restoration in urban green spaces: Does setting type make a difference? Landscape and Urban Planning, 127, 173-181.

van Dillen, S. M., de Vries, S., Groenewegen, P. P., \& Spreeuwenberg, P. (2012). Greenspace in urban neighbourhoods and residents' health: adding quality to quantity. Journal of epidemiology and community health, 66(6), e8. https://doi.org/10.1136/jech.2009.104695

Van Herzele, A., \& de Vries, S. (2012). Linking green space to health: A comparative study of two urban neighbourhoods in Ghent, Belgium. Population and Environment, 34(2), 171193.

Vasegh, S., \& Mohammadi, M. R. (2007). Religiosity, anxiety, and depression among a sample of Iranian medical students. The International Journal of Psychiatry in Medicine, 37(2), 213-227.

Von Benzon, N. (2011). Who's afraid of the big bad woods? Fear and learning disabled children's access to local nature. Local Environment, 16(10), 1021-1040.

Wan, C., Shen, G. Q., \& Choi, S. (2020). Effects of physical and psychological factors on users' attitudes, use patterns, and perceived benefits toward urban parks. Urban Forestry \& Urban Greening, 51,126691.

Wahed, W. Y. A., \& Hassan, S. K. (2017). Prevalence and associated factors of stress, anxiety and depression among medical Fayoum University students. Alexandria Journal of Medicine, 53(1), 77-84.

Wilson, R. (2007). Nature and young children: Encouraging creative play and learning in natural environments. Routledge

White, M., Smith, A., Humphryes, K., Pahl, S., Snelling, D., \& Depledge, M. (2010). Blue space: The importance of water for preference, affect, and restorativeness ratings of natural and built scenes. Journal of Environmental Psychology, 30(4), 482-493.

WHO Commission on Social Determinants of Health, \& World Health Organization. (2008). Closing the gap in a generation: health equity through action on the social determinants of health: Commission on Social Determinants of Health final report. World Health Organization. 
Weinstein, N., Przybylski, A. K., \& Ryan, R. M. (2009). Can nature make us more caring? Effects of immersion in nature on intrinsic aspirations and generosity. Personality and Social Psychology Bulletin, 35, 1315-1329.

Wells, N. M., \& Evans, G. W. (2003). Nearby nature: A buffer of life stress among rural children. Environment and Behavior, 35(3), 311-330.

West, W. (2004). Spiritual issues in therapy: Relating experience to practice. Palgrave Macmillan.

Wyles, K. J., Pahl, S., \& Thompson, R. C. (2014). Perceived risks and benefits of recreational visits to the marine environment: Integrating impacts on the environment and impacts on the visitor. Ocean \& Coastal Management, 88, 53-63.

Xu, Y., Qi, J., Yang, Y., \& Wen, X. (2016). The contribution of lifestyle factors to depressive symptoms: A cross-sectional study in Chinese college students. Psychiatry Research, 245, 243-249.

Yadav, R., Khanna, A., \& Singh, D. (2017). Exploration of relationship between stress and spirituality characteristics of male and female engineering students: A comprehensive study. Journal of Religion and Health, 56(2), 388-399.

Yahaya, N., Momtaz, Y. A., Othman, M., Sulaiman, N., \& Mat, F. (2012). Spiritual well-being and mental health among Malaysian adolescents. Life Science Journal, 9(1), 440-448.

Yamaguchi, M., Deguchi, M., \& Miyazaki, Y. (2006). The effects of exercise in forest and urban environments on sympathetic nervous activity of normal young adults. Journal of International Medical Research, 34(2), 152-159.

Zafirah, H. R., Salwa, H. M. S., Kamaruddin, N. F. L., Ahmad, M. W., Nurzhafri, Z., Aini, M. N. N., Hamdie, Y. E., \& Razali, S. (2016). Psychological Distress and Lifestyle of Malay Medical Students. Journal of Medical Education, 15(2).

Zelenski, J. M., Dopko, R. L., \& Capaldi, C. A. (2015). Cooperation is in our nature: Nature exposure may promote cooperative and environmentally sustainable behavior. Journal of Environmental Psychology, 42, 24-31. 